\title{
Characterization of Antimicrobial, Antioxidant, Anticancer Property and Chemical Composition of Michelia champaca Seed and Flower Extracts
}

\author{
${ }^{*}$ Lee Seong Wei ${ }^{1}$, Wendy Wee ${ }^{2}$, Julius Yong Fu Siong ${ }^{3}$, Desy Fitrya Syamsumir ${ }^{3}$ \\ ${ }^{1}$ Department of Agro Industry, Faculty of Agro Industry and Natural Resources, Universiti Malaysia Kelantan, \\ Pengkalan Chepa, 16100, Kota Bharu, Kelantan, Malaysia. \\ 2Department of Fisheries Science and Aquaculture, Faculty of Agrotechnology and Food Science, Universiti Malaysia \\ Terengganu, Kuala Terengganu, 21030, Terengganu, Malaysia. \\ ${ }^{3}$ Institute of Marine Biotechnology, Universiti Malaysia Terengganu Kuala Terengganu, 21030, Terengganu, Malaysia.
}

Original Research Article

\begin{abstract}
This study was carried out to characterize antimicrobial, antioxidant and anticancer activities of Michelia champaca seed and flower extracts. The main objective of the present study was to reveal the medicinal values of M. champaca seed and flower for human uses. Antimicrobial property of M. champaca seed and flower extracts were revealed by using two fold microdilution method whereas antioxidant activity of the extract was determined with DPPH radical scavenging method. The anticancer property of the plant extract was revealed through Colorimetric MTT (tetrazolium) assay. The minimum inhibitory concentration values of M. champaca seed and flower extracts ranged from 15.6 to $125 \mathrm{mg} / \mathrm{l}$ and 7.8 to $62.5 \mathrm{mg} / \mathrm{l}$, respectively in which both of the plant extracts were found can inhibit the growth of all the tested bacterial isolates namely A. hydrophila, E. tarda, E. coli, Flavobacterium sp., Klebsiella sp., P. aeruginosa, Salmonella sp., V. alginolyticus, V. cholerae and V. parahaemolyticus. M. champaca flower extract was able to control the growth of E. tarda, E. coli, Flavobacterium sp., P. aeruginosa and V. cholerae at the concentration of $7.8 \mathrm{mg} / \mathrm{l}$ whereas A. hydrophila, Klebsiella sp. and V. alginolyticus were failed to grow at the concentration $15.6 \mathrm{mg} / \mathrm{l}$. The M. champaca flower extract was also able to control the growth of Salmonella sp. and V. parahaemolyticus at the concentration of $62.5 \mathrm{mg} / \mathrm{l}$. At the maximum concentration of M. champaca seed and flower extracts were found can inhibit only $40 \%$ of DPPH whereas the IC 50 value of M. champaca seed and flower extract against MCF-7 cells was $1.98 \pm 0.31 \mu \mathrm{g} / \mathrm{ml}$ and $1.86 \pm 0.21 \mu \mathrm{g} / \mathrm{ml}$, respectively. A total of 9 chemical compounds were successfully identified in M. champaca's flower extract whereas 37 chemical compounds were found in the leaf extract. The findings of the present study indicated that medicinal values of $\mathrm{M}$. champaca seed \& flower extracts in terms of antimicrobial and anticancer are promising.
\end{abstract}

Key words: Antioxidant, Anticancer, Antimicrobial, Chemical compound, Michelia champaca

\section{INTRODUCTION}

Michelia champaca is a member of family Magnoliaceae. It is well known and widely used in traditional medicine such as fever, colic, leprosy, post partum protection (Perry, 1980), eye disorder and many more. This plant was

\footnotetext{
*Corresponding Author

Lee Seong Wei

Department of Agro Industry, Faculty of Agro Industry and Natural Resources Universiti Malaysia Kelantan, Pengkalan Chepa, 16100, Kota Bharu, Kelantan, Malaysia E-mail: leeseongwei@yahoo.com
}

claimed possesses various pharmacological properties such as antipyretic, antiinflammatory (Vimala et al., 1997), insecticidal, antimicrobial and etc. Furthermore, Atjanasuppat et al. (2009) reported that this plant can be as remedy of antiuretic, carminative and antidinic. Several compounds of this plant were also characterized and identified such as alkaloids, saponins, tannins, sterols, flavonoids and triterpenoids in the study of Khan et al. (2002). The increasing of incidence of antibiotic resistance case among pathogenic bacteria lead to the most of commercial antibiotics were no longer effectively in controlling bacteria 
diseases. Subsequently, it is a must to find the alternative antimicrobial agent especially from plants. As oxidative stress may lead to many human diseases, the use of antioxidants in pharmacology is intensively studied, particular as treatment for stroke and neurodegenerative diseases. Apart of oxidative stress, cancer is recognized as the new emerged human disease that had killed a lot of people. Thus, this study was carried out to reveal the potential of Michelia champaca to be used as a natural health food supplement. Till present, the information of medicinal values of $M$. champaca is still lacking in the literature. Therefore, this study was carried out to enrich the information of the medicinal property of $M$. champaca in terms of antimicrobial, antioxidant and anticancer as well as its chemical composition in the literature.

\section{MATERIALS AND METHODS}

\section{Plant material}

The plant sample was purchased from herbal nursery located at Pasir Puteh, Kelantan, Malaysia. The fresh plant sample was oven dried at $37^{\circ} \mathrm{C}$ for 4 days. Next, the plant sample was freeze dried prior to extraction using $70 \%$ methanol and concentrated at $1 \mathrm{~g} / \mathrm{ml}$. Finally, the plant extraction was kept in $-20^{\circ} \mathrm{C}$ until further use.

\section{Bacteria isolates}

All bacterial isolates were provided by Universiti Malaysia Kelantan namely Aeromonas hydrophila, Escherichia coli, Edwardsiella tarda, Flavobacterium spp., Klebsiella pneumonia, Salmonella typhi, Vibrio alginolyticus, $V$. parahaemolyticus, V. cholerae and Pseudomonas aeruginosa. These bacteria were isolated from various aquatic animals and kept in tryptic soy agar (TSA) for further uses.

\section{Minimum inhibitory concentration (MIC) determination}

The values of minimum inhibitory concentration (MIC) of M. champaca seed and flower extracts against bacterial isolates were determined through a two-fold broth micro dilution method
(Lee and Najiah, 2008; Lee et al., 2009). The bacterial isolates were cultured in tryptic soy broth for $24 \mathrm{~h}$ at room temperature and the concentration of these cultures were adjusted to $10^{9} \mathrm{CFU} \mathrm{mL} \mathrm{mL}^{-1}$ by using physiological saline. The concentration was cross check with a Biophotometer (Eppendorf, Germany). The bacterial suspensions were then inoculated into a microtiter plate that contained a serial dilution of $M$. champaca seed and flower extracts. The microplate was then incubated at room temperature for $24 \mathrm{~h}$. The MIC values were defined as the lowest concentration of the $M$. champaca seed and flower extracts in the wells of the microtiter plate that showed no visible turbidity after $24 \mathrm{~h}$ incubation.

Determination of antioxidant activity with $\alpha$, $\alpha$-diphenyl- $\beta$-picrylhydrazyl (DPPH) radical scavenging method

DPPH radical scavenging method was conducted as described by Blois (1958), Yen and Duh (1994), Brand-William et al. (1995) and Gadow et al. (1997) with some modifications. The assay was carried in a 96 wells elisa plate with three replicates. $5 \mu \mathrm{l}$ of the sample $(0.5$ $\mathrm{mg} / \mathrm{ml}$ ) solution was added into the well followed by $200 \mu \mathrm{DPPH}$. The absorbance of the sample was recorded by using ELISA reader for ever interval $6 \mathrm{~s}$. The percentage inhibition of $\mathrm{DPPH}$ radical was calculated based on the absorbance.

\section{Cancer cell lines}

The human breast adenocarcinoma (MCF-7) cell line was derived from Institute of Marine Biotechnology, Universiti Malaysia Terengganu. All the cells were grown in standard cell medium (RPMI 1640) supplemented with 5\% fetal bovine serum in a $5 \% \mathrm{CO}_{2}$ atmosphere. The cells was then transferred into microplate at the concentration of $1 \times 10^{2}$ cells per well for cytotoxicity test of the plant extract. At 48 h, proliferation was measured by the MTT colorimetric assay. The $\mathrm{IC}_{50}$ value was calculated from the following formula as described Adebayo et al. (2010). 
Table 1. The sensitivity of bacterial isolates against Michelia champaca seed and flower extracts.

\begin{tabular}{ccc}
\hline \multirow{2}{*}{ Bacterial isolates } & \multicolumn{2}{c}{ Minimum Inhibitory Concentration (MIC) (mg/l) } \\
\cline { 2 - 3 } & Michelia champaca seed & Michelia champaca flower \\
\hline Aeromonas hydrophila & 31.3 & 15.6 \\
Edwardsiella tarda & 15.6 & 7.8 \\
Escherichia coli & 15.6 & 7.8 \\
Flavobacterium sp. & 15.6 & 7.8 \\
Klebsiella sp. & 31.3 & 15.6 \\
Pseudomonas aeruginosa & 15.6 & 7.8 \\
Salmonella sp. & 125.0 & 62.5 \\
Vibrio alginolyticus & 31.3 & 15.6 \\
Vibrio cholerae & 15.6 & 7.8 \\
Vibrio parahaemolyticus & 125.0 & 62.5 \\
\hline
\end{tabular}

$\log _{10}\left(I C_{50}\right)=\frac{\log _{10} C_{L}\left(I_{H}-50\right)+\log _{10} C_{H}\left(50-I_{L}\right)}{I_{H}-I_{L}}$

$\mathrm{IC}_{50}=10 \log _{10}\left(\mathrm{IC}_{50}\right)$

Where:

Ін: I\% above $50 \%$

IL: I\% below $50 \%$

$\mathrm{C}_{\mathrm{H}}$ : High drug concentration

$\mathrm{C}_{\mathrm{L}}$ : Low drug concentration

\section{Colorimetric MTT (tetrazolium) assay}

Colorimetric MTT (3-(4, 5-dimethythiazol-2-yl)2,5-diphenyl tetrazolium bromide) (Sigma, USA) assay was carried out as described by Mosmann (1983). $10 \mu \mathrm{l}$ of MTT solution $(5 \mathrm{mg} / \mathrm{ml})$ was added to all wells of 96 wells micro plate followed by $4 \mathrm{~h}$ incubation at $37^{\circ} \mathrm{C}$. Acid isopropanol was added to all wells for dissolving the dark blue crystals. The microplate plate was then read on an ELISA reader at wavelength $570 \mathrm{~nm}$ within $1 \mathrm{~h}$ after adding isopropanol.

\section{Bioactive compound characterization}

The chromatographic procedure was carried out using a Shimadzu QP2010-GC-MS with autosampler. The sample was diluted 25 times with

Table 2. IC 50 value of $M$. champaca seed and flower extract against MCF-7 cells.

\begin{tabular}{cc}
\hline Michelia champaca & $\mathrm{IC}_{50}(\mu \mathrm{g} / \mathrm{ml})$ \\
\hline Seed & $1.98 \pm 0.31$ \\
Flower & $1.86 \pm 0.21$ \\
\hline
\end{tabular}

acetone and $1 \mu \mathrm{l}(1 \mu \mathrm{g} / \mathrm{ml})$ of sample was injected into a column. A fused silica capillary column HP5-MS (30m x 0.32mm, film thickness $0.25 \mu \mathrm{m}$ ) was used. Helium was the carrier gas, and a split ratio of $1 / 100$ was used. The oven temperature used was maintained at $60^{\circ} \mathrm{C}$ for 8 $\mathrm{min}$. The temperature was then gradually raised at a rate of $3^{\circ} \mathrm{C}$ per min to $180^{\circ} \mathrm{C}$ and maintained at $180^{\circ} \mathrm{C}$ for $5 \mathrm{~min}$. The temperature at the injection port was $250^{\circ} \mathrm{C}$. The components of the test solution were identified by comparing the spectra with those of known compounds stored in internal library as described by Lee et al. (2009). The identification was accomplished using computer searches on a internal data library. In some cases, when identical spectra have not been found, only the structural type of the corresponding component was proposed on the basis of its mass-spectral fragmentation. If available, references compound were cochromatographed to confirm GC retention times (Bankova et al., 2002).

\section{RESULT AND DISCUSSION}

The MIC values of $M$. champaca seed and flower extracts ranged from 15.6 to $125 \mathrm{mg} / \mathrm{l}$ and 7.8 to $62.5 \mathrm{mg} / \mathrm{l}$, respectively (Table 1). E. tarda, E. coli, Flavobacterium sp., $P$. aeruginosa and $V$. cholerae were failed to grow at the concentration of $15.6 \mathrm{mg} / \mathrm{l}$ of $M$. champaca extract. At the concentration of $31.3 \mathrm{mg} / \mathrm{l}$ of $M$. champaca seed extract was found can inhibit the growth of $A$. hydrophila, Klebsiella sp. and $V$. alginolyticus whereas at the concentration of $125 \mathrm{mg} / \mathrm{l}$ of $M$. 
Table 3. Compound composition of Michelia champaca's flower.

\begin{tabular}{cc} 
Compound & Compound Composition (\%) \\
\hline 9,12-Octadecadienoic acid, methyl ester, (E,E)- & 39.55 \\
2-Propanone, 1-phenoxy & 25.50 \\
Benzofuran, 2,3-dihydro- & 9.89 \\
5,8,11,14-Eicosatetraenoic acid, methyl ester, (all-Z)- & 7.05 \\
Butanoic acid, 2-methyl-3-oxo-, ethyl ester & 4.10 \\
7-Oxabicyclo[4.1.0]heptanes, 1-methyl-4-(2-methyloxiranyl)- & 3.69 \\
7-Oxabicyclo[4.1.0] heptanes, 1-methyl-4-(2-methyloxiranyl)- & 2.95 \\
Oleic acid & 2.79 \\
Camphorsulfonic acid & 1.98 \\
3 unidentified compounds & 2.50 \\
\hline Total & $\mathbf{1 0 0}$ \\
\hline
\end{tabular}

champaca seed extract was able to control the growth of $V$. parahaemolyticus. $M$. champaca flower extract was able to control the growth of E. tarda, E. coli, Flavobacterium sp., P. aeruginosa and $V$. cholerae at the concentration of $7.8 \mathrm{mg} / 1$ whereas $A$. hydrophila, Klebsiella sp. and $V$. alginolyticus were failed to grow at the concentration $15.6 \mathrm{mg} / \mathrm{l}$. The $M$. champaca flower extract was also able to control the growth of Salmonella sp. and $V$. parahaemolyticus at the concentration of $62.5 \mathrm{mg} / \mathrm{l}$. At the maximum concentration of $M$. champaca seed and flower extracts were found can inhibit only $40 \%$ of $\mathrm{DPPH}$ whereas the $\mathrm{IC}_{50}$ value of $M$. champaca seed and flower extract against MCF-7 cells was $1.98 \pm 0.31 \mu \mathrm{g} / \mathrm{ml}$ and $1.86 \pm 0.21 \mu \mathrm{g} / \mathrm{ml}$, respectively (Table 2). A total of 9 chemical compounds were successfully identified in $M$. champaca's flower extract in which 9,12Octadecadienoic acid, methyl ester, (E,E)$39.55 \%$ and 2-Propanone, 1-phenoxy 25.50\% were the major compounds (Table 3). This was followed by Benzofuran, 2,3-dihydro- 9.89\%, 5,8,11,14-Eicosatetraenoic acid, methyl ester, (allZ)- 7.05\%, Butanoic acid, 2-methyl-3-oxo-, ethyl ester $4.10 \%$, 7-Oxabicyclo[4.1.0]heptanes, 1methyl-4-(2-methyloxiranyl)- $2.95 \%$, Oleic acid $2.79 \%$, Camphorsulfonic acid $1.98 \%$ and another 3 unidentified compounds $2.50 \%$. A total of 37 chemical compounds were successfully identified in the M. champaca's leaf extract (Table 4). They were Naphthalenemethanol $7.70 \%$, Acetic acid 6.68\%, 2, 3-Butanediol 6.46\%, Phenol $5.34 \%$, Andrographolide 4.56\%, 5-Dodecyne $3.61 \%$, Pimaric acid $3.08 \%$, OrthoFormylphenoxyacetic acid $2.80 \%$, Succinamic acid 2.78\%, Benzoic acid 2.66\%, Methyl $\beta$-dgalactopyranoside $2.45 \%$, 2-Propanone, 1hydroxy- $1.93 \%$, Trimethoxyvinylsilane $1.81 \%$, Androstane-3, 17-diol, 17-methyl- 1.59\%, Cyclooctane, (methoxymethoxy) 1.52\%, 1, 2Benzenediol 1.44\%, Propane, 1-bromo-2-methyl$1.34 \%$, Octadecatrienoic acid 1.19\%, 1-Pentylhexobarbital 1.13\%, Hydroquinone 1.12\%, 1Alanine, N-isobutoxycarbonyl-, butyl ester $1.01 \%$, Benzofuran, 2, 3-dihydro 0.96\%, Phenol 0.91\%, (E)-3(10)-Caren-4-ol 0.91\%, 1-Alanine, Nallyloxycarbonyl-, undec-10-enyl ester $0.83 \%$, Heptenoic acid 0.73\%, Imidazole-5-pentanoic acid $0.70 \%$, Bisnor-7-desoxycholic acid $0.68 \%$, 2, 5-Dimethoxy-4-(methylsulfonyl) ampheta-mine $0.67 \%$, Valeric acid $0.65 \%$, 2-Furanmethanol $0.64 \%$, 5-Eicosyne $0.63 \%$, Tromethamine $0.55 \%$, 2-Cyclopenten-1-one, 2-hydroxy- $0.54 \%$, Glycerin $0.50 \%$, 1-Pentyl-hexobarbital $0.50 \%$, Pholedrine $\quad 0.47 \%$ and 11 unidentified compounds $22.97 \%$.

In the present study, both of the plant extracts were found successfully inhibited the growth of all the tested bacterial isolates. This was supported by the study of Khan et al. (2002) in which they found that leaves and seeds extracts of $M$. champaca showed inhibitory activity against Gram positive, negative bacteria and fungi as well as a protozoan, Trichomonas vaginalis. Furthermore, Octadecadienoic acid, Butanoic acid, Oleic acid, Camphorsulfonic acid, Acetic acid and Pimaric acid in the plant extracts which were responsible to the antimicrobial activity of the plant extracts. Thus, we may conclude that the antimicrobial property of $M$. 
Table 4. Compound composition of Michelia champaca's leaf.

\begin{tabular}{|c|c|}
\hline Compound & $\begin{array}{c}\text { Compound } \\
\text { Composition } \\
(\%)\end{array}$ \\
\hline Naphthalenemethanol & 7.70 \\
\hline Acetic acid & 6.68 \\
\hline 2, 3-Butanediol & 6.46 \\
\hline Phenol & 6.25 \\
\hline Andrographolide & 4.56 \\
\hline 5-Dodecyne & 3.61 \\
\hline Pimaric acid & 3.08 \\
\hline Ortho-Formylphenoxyacetic acid & 2.80 \\
\hline Succinamic acid & 2.78 \\
\hline Benzoic acid & 2.66 \\
\hline Methyl $\beta$-d-galactopyranoside & 2.45 \\
\hline 2-Propanone, 1-hydroxy- & 1.93 \\
\hline Trimethoxyvinylsilane & 1.81 \\
\hline Androstane-3, 17-diol, 17-methyl- & 1.59 \\
\hline Cyclooctane, (methoxymethoxy) & 1.52 \\
\hline 1, 2-Benzenediol & 1.44 \\
\hline Propane, 1-bromo-2-methyl- & 1.34 \\
\hline Octadecatrienoic acid & 1.19 \\
\hline 1-Pentyl-hexobarbital & 1.13 \\
\hline Hydroquinone & 1.12 \\
\hline $\begin{array}{l}\text { 1-Alanine, N-isobutoxycarbonyl-, } \\
\text { butyl ester }\end{array}$ & 1.01 \\
\hline Benzofuran, 2, 3-dihydro & 0.96 \\
\hline (E)-3(10)-Caren-4-ol & 0.91 \\
\hline $\begin{array}{l}\text { 1-Alanine, } \mathrm{N} \text {-allyloxycarbonyl-, } \\
\text { undec-10-enyl ester }\end{array}$ & 0.83 \\
\hline Heptenoic acid & 0.73 \\
\hline Imidazole-5-pentanoic acid & 0.70 \\
\hline Bisnor-7-desoxycholic acid & 0.68 \\
\hline $\begin{array}{l}\text { 2,5-Dimethoxy-4-(methylsulfonyl) } \\
\text { amphetamine }\end{array}$ & 0.67 \\
\hline Valeric acid & 0.65 \\
\hline 2-Furanmethanol & 0.64 \\
\hline 5-Eicosyne & 0.63 \\
\hline Tromethamine & 0.55 \\
\hline 2-Cyclopenten-1-one, 2-hydroxy- & 0.54 \\
\hline Glycerin & 0.50 \\
\hline 1-Pentyl-hexobarbital & 0.50 \\
\hline Pholedrine & 0.47 \\
\hline 11 unidentified compounds & 22.97 \\
\hline Total & 100.00 \\
\hline
\end{tabular}

champaca was undoubtedly. Although, there are studies revealed the antimicrobial property of $M$. champaca but they do not further the study on the MIC values of the plant extracts. Therefore, the present study provided the MIC values of the plant extracts against the tested bacterial isolates that may be useful for the in vivo test in the near future.
In so far, there is only one study involved in the work of antioxidant activity of $M$. champaca in the literature where Hossain et al. (2009) claimed that M. champaca leaf extract possesses antioxidant activity against DPPH. In addition, in the present study found that $M$. champaca seed and flower extracts have antioxidant activity against DPPH as well. Hence, we may conclude that $M$. champaca leaf, seed and flower can be used as an antioxidant agent for medicinal uses. Furthermore, this was supported by the finding of the present study in which Octadecadienoic acid, Butanoic acid, Oleic acid, Camphorsulfonic acid, Acetic acid, Pimaric acid, Phenol and Benzoic acid were found in the plant extracts that responsible to the antioxidant activity of the plant extracts.

From the literature survey, no much works were done on the anticancer activity of $M$. champaca. For instance, only the study of Atjanasuppata et al. (2009) reported M. champaca leaf extract showed the inhibitory activity against C32 cells but failed to response to Hela cells. Therefore, this is the first report on the positive response of M. champaca flower and seed extracts to MCF-7 cells. Furthermore, several compounds such as Octadecadienoic acid, Butanoic acid, Oleic acid, Camphorsulfonic acid, Acetic acid, Pimaric acid, Phenol and Benzoic acid that responsible to the anticancer activity were found in the plant extracts. Therefore, the findings of the present study convince us that $M$. champaca possesses anticancer property.

In conclusion, the findings of the present study and the information from the literature survey, we may conclude that $M$. champaca possesses high medicinal values. However, further study still need to be carried out in terms of in vivo test before it was commercialized for public uses.

\section{ACKNOWLEDGEMENT}

This project was funded by Universiti Malaysia Kelantan short term projects (R/SGJP/A03.00/00387A/001/2009/000018 and R/SGJP/A03.00/00302A/001/2009/000019) 


\section{REFERENCES}

Adebayo AH, Tan NH, Akindahunsi AA, Zeng GZ, Zhang YM. (2010), Anticancer and antiradical scavenging activity of Ageratum conyzoides L. (Asteraceae). Phcog. Mag. 6: 62-66.

Atjanasuppata K, Wongkhama W, Meepowpan P, Kittakoop P, Sobhon P, Bartlett A, Whitfield PJ. (2009), In vitro screening for anthelmintic and antitumour activity of ethnomedicinal plants from Thailand. J. Ethnopharmacol. 123: 475-482.

Bankova V, Popova M, Bogdanov S, Sabatini AG. (2002), Chemical composition of European propolis: expected and unexpected results. Z. Naturforsch. 57C: 530-533.

Blois MS. (1958), Antioxidant determination by the use of a stable free radical. Nature 181: 1199-1200.

Brand-Williams, W, Cuvelier ME, Berset C. (1995), Use a free radical method to evaluate antioxidant activity. Lebensm. Wiss. Technol. 28: 25-30.

Gadow AW, Joubert E, Hansmann CF. (1997), Comparison of the antioxidant activity of rooibos tea (Aspalathus linearis) with green, oolong and black tea. Food Chem. 60 (1): 73-77.

Hossain MM, Jahangir R, Raquibul Hasan SM, Akter R, Ahmed T, Islam MI, Faruque A. (2009), Antioxidant, analgesic and cytotoxic activity of Michelia champaca Linn. leaf. Stamford J, Pharma. Sci. 2 (2): 1-7.

Lee SW, Najiah M. (2008), Inhibition of Edwardsiella tarda and other fish pathogens by Allium sativum L. (Alliaceae) Extract. American-Eurasian J. Agric. E Environ. Sci. 3 (5): 692-696.

Lee SW, Najiah M, Wendy W, Nadirah M. (2009), Chemical composition and antimicrobial activity of the essential oil of Syzgium aromaticum flower bud (clove) against fish systemic bacteria isolated from aquaculture sites. Fron. Agricult. China 3 (3): 332336.

Khan MR, Kihara M, Omoloso AD. (2002), Antimicrobial activity of Michelia champaca. Fitoterapia 73: 744-748.

Mosmann T. (1983), Rapid colorimetric assay for cellular growth and survival: application to proliferation and cytotoxicity assays. J. Immunol. Methods 65: 5563.

Perry LM. (1980), Medicinal plants of East and Southeast Asia: attributed properties and uses. Cambridge, Massachusetts, and London: The MIT Press. p. 154

Vimala R, Nagarajan S, Alam M, Susan T, Joy S. (1997), Antiinflammatory and antipyretic activity of Michelia champaca Linn., (white variety), Ixora brachiata Roxb. and Rhynchosia cana (Willd.) D.C. flower extract. Indian J. Exp. Biol. 35:1310.
Yen GC, Duh PD. (1994), Scavenging effect of methanolic extracts of peanut hulls on free radical and active oxygen species. J. Agric. Food Chem. 42: 629-632. 